\title{
THE CONSTRUCTION OF MORALITY EDUCATIONAL CONCEPT (ANALYSIS OF THINKING HAMKA)
}

\author{
M Bahrudin \\ mbahruddin@gmail.com
}

\begin{abstract}
This research is motivated by the problems of moral degradation of teenagers and the role of the model in Indonesian society today. Therefore, it is needed to examine the characters who become role models and thoughts about manners to produce the seeds of the successor of the noble nation of noble character. This research uses qualitative approach. This means that the approach by thinking the opinions of experts or phenomena that exist in people's lives. This type of research using research type library research that collects data or scientific papers that aims with the object of research or collecting data that is literary. In collecting data, the author uses documentation techniques. As for the technique of data analysis using content analysis, namely data processing by separate sorting related to the discussion of some ideas or thoughts of educational leaders who later described, discussed and criticized. The results of this study conclude that the concept of moral character education perspective based on Al-Qur'an and Sunnah Rasulullah SAW and Reason. The goal of human rights perspective education is to reach the i'tidal (soul balance) achieved by developing four factors, namely syaja'ah, 'iffah, wisdom, and' is. A prominent method of morality education of HAMKA is the method of virtue, exemplary method, live in method, and method of habituation. The most appealing evaluation for character education of human rights perspective is muhasabah (self-evaluation).
\end{abstract}

Keywords: Concept of Education, Character, Hamka

\section{A. Introduction}

When the Indonesians agreed to proclaim Indonesian independence on August 17,1945 , the founding fathers realized that there were at least three major challenges to be faced. The first challenge is to establish a united and sovereign state. The second 
challenge is to build a nation. And the third challenge is to build character. These three things are clearly visible in the concept of nation-state and nation-building of the nation. In its implementation then efforts to establish the state is relatively faster when compared with efforts to build the nation and character. The latter two proved to be endeavored continuously, should not be broken throughout the history of Indonesian national life. ${ }^{1}$ And in the opinion of the author, one of the steps to build a nation and character is with education.

Many people give meaning to education is very diverse, even in accordance with their respective views. Azyumardi Azra provides an understanding of "education" is a process in which a nation prepares its young generation to live life and to meet the purpose of life effectively and efficiently. In fact, he asserted that education is a process whereby a nation or country foster and develop self-awareness among individuals. ${ }^{2}$

Besides that, dedication is something that is really implanted in addition to forge physical, mental, and moral for individuals, so that they become cultured human beings so that they are expected to fulfill their duties as human created by God of the Universe, as a perfect and chosen creature as his vicegerent on this earth who at the same time becomes a citizen who is meaningful and beneficial to a country. ${ }^{3}$

The rise of the world of education pioneered by our Hero Ki Hajar Dewantara to oppose the invaders in the past, it is very meaningful if we look carefully. For that is not too much if the nation of Indonesia as a great nation to commemorate the National Education Day which falls every May 2nd, as a form of reflection of appreciation as well as a form of homage to the pioneers of independence and national heroes of pioneers.

In addition, how the spirit of nationalism and its struggle and the insight of nationality possessed by our predecessors is enormous, even willing to sacrifice for the people and nation. But its development today is very ironic. Many of our youth who do not have a great soul, even very worrying.

\footnotetext{
${ }^{1}$ Muchlas Samani dan Hariyanto, Konsep dan Model Pendidikan Karakter, (Bandung: Remaja Rosdakarya, 2012), cet. Ke-2, 1.

${ }^{2}$ Azyumardi Azra, Paradigma Baru Pendidikan Nasuonal: Rekonstruksi Dan Demokratisasi, (Jakarta: Kompas, 2002), 8.

${ }^{3}$ Masnur Muslich, Pendidikan Karakter: Menjawab Tantangan Krisisi Multidimensional, (Jakarta: Bumi Aksara, 2011), cet. Ke-2, 48.
} 
If we observe broadly, the achievement of our national education is still far from expectations, let alone to be able to compete as competitive with the development of education at the global level. Both quantitatively and qualitatively, national education has many fundamental flaws. Even national education, in many cases, not only has not succeeded in improving the intelligence and skills of students, but also failed in shaping the character and personality (nation and character building) even the existence of moral degradation. ${ }^{4}$

Indeed, the character education has been applied for religious education, especially Islamic religious education, in schools has been given in various aspects, namely faith, worship, shari'a, morals, Al-Qur'an, mua'malah and history of Islam. In the material directly related to the education of character is the character. In such a way, moral education is directly related to character education.

Caused by a variety of factors, the actualization of school education has not shown encouraging results. This is due, among other things, first, the religion education is too cognitive, the approach is too brain-oriented, telling what is good and what is bad, which is right and which is not right, and so on. The affective and psychological aspect is not offended, even if it is very minor, second, the problem that comes from the child itself, coming from a diverse family background, some of which are well-orchestrated in the house and some have not. Third, impressed that the responsibility of religious education is on the shoulders of religious teachers only. Fourth, the limited time available with the weight of religious education material that is proclaimed. ${ }^{5}$

The orientation of national education which tends to forget the development of the value dimension (affective domain) has been detrimental to individual and collective investigators. The tendency that arises is, learners will know a lot about something, but it becomes less have a value system, attitude, interest or appreciation positively to what is known. Children will experience intellectual development is not balanced with the maturity of personality so that gave birth to a specialist figure who is less concerned with the surrounding environment and susceptible to distortion values. As a result,

\footnotetext{
${ }^{4}$ Ibid., 49-50.

${ }^{5}$ Su'adah, Pendidikan Budi Pekerti: Integrasi Nilai Moral Agama Dengan Pendidikan Budi Pekerti. Ibid,134.
} 
learners will easily slip in the practice of moral offenses because the value system that should be the standard and benchmark of everyday behavior has not been so solid. ${ }^{6}$

Reflecting on the limited efforts of educational institutions in equipping the moral values of learners has so far inspired the emergence of commitment from some circles to provide moral education. Character education as a part that enrich religious education aims to develop the values, attitudes and behavior of students who radiate noble character or morality. ${ }^{7}$ This is in harmony with the important goal of Islamic education which is to reach a noble and perfect character, because the spirit of Islamic education is moral education. ${ }^{8}$

Based on the above description the researcher tries to study the thoughts of Haji Abdul Malik Karim Amrullah (HAMKA) As one of the figures as well as great ulama' in Minangkabau. This study aims to know his thoughts in the field of moral education for the community, especially the Islamic community. Moreover, some of HAMKA's thoughts about character education in his own book there stated that all his thoughts about education is more emphasis on character education or good morality, so in this case, the authors want to know more in a few further opinions of HAMKA which is concerned about character education.

Some of the reasons that become a benchmark to examine the thoughts of HAMKA is that he is not only a scientist or a writer, but a figure of 'ulama' in the modern era that contributes a lot to the development of civilization and the emergence of the dynamics of society's (Islam). He is a 'ulama' figure who seeks to change the traditionalist lifestyle to the pattern of life and rational, he is also a figure of educators of people and a figure that have vast knowledge. In addition, in general his works is the synthesis of the development of educational patterns implemented by Islamic humans at that time (Minangkabau Society). ${ }^{9}$ Based on this is a fundamental reason for the author to discuss the issue.

\section{B. Research Methods}

\footnotetext{
${ }^{6}$ Suyanto dan Jihad Hisyam, Refleksi dan Reformasi Pendidikan di Indonesia Memasuki Milenium Ketiga, (Yogyakarta: Adi Cita Karya, 2000), 153.

${ }^{7}$ Haidar Putra Dauly, Pendidikan Islam dalam Sistem Pendidikan Nasional di Indoenesia,(Jakarta: Prenada Media, 2004), 220.

${ }^{8}$ M. Athiyah Al-Abrasy, Dasar-Dasar Pokok Pendidikan Islam, (Jakarta: Bulan Bintang, 1993), 1.

${ }^{9}$ Haidar Musyafa, HAMKA: Sebuah Novel Biografi, (Tangerang Selatan: Imania, 2017), cet. Ke- 2, 8.
} 
The approach in this research uses a qualitative approach, namely an approach used to process data without using numerical calculations, but through the exposure of opinions of experts or phenomena that exist in the life of the community. ${ }^{10}$

This type of research uses the type of research library research that is collecting data or scientific papers that aims with the object of research or collecting data that is bibliographic or the study conducted to solve a problem based on the basis of critical and in-depth review of the relevant literature materials.

In this research, the researcher uses two kinds of data source that is primary data source and secondary data source. Primary data sources are works written by the person in question. While the secondary data source is the literature either in the form of books or writings of other figures in which there is a description of the thoughts of HAMKA about education or more specifically about the education of morality or other literature in accordance with the discussion.

In the data collection the author uses documentation techniques means that data collected from documents either in the form of books, journals, magazines, articles and other scientific papers related to the title raised by the author about moral education for learners that is the primary source of the essay of HAMKA itself and also secondary books by other figures.

\section{Results and Discussion}

\section{Definition of Morality Education According to HAMKA}

A multi-faceted HAMKA figure. Apart from being a scholar and a poet, he is also a thinker. Among his thoughts is the idea of education. The importance of human seeking knowledge, according to HAMKA, is not only to help human beings get a decent living, but more than that, with human knowledge will be able to know his God, refine his morals, and always try to seek the pleasure of Allah. ${ }^{11}$ HAMKA distinguishes the meaning of education and teaching. According to him, education is a series of efforts by educators to help shape the character, mind, morals, and personality of

\footnotetext{
${ }^{10}$ Lexy J. Moleong, Metodologi Penelitian Kualitatif, (Bandung: Remaja Rosdakarya, 2001), 1.

${ }^{11}$ Syamsul Kurniawan, Erwin Mahrus, Jejak Pemikiran Tokoh Pendidikan Islam, 230.
} 
learners, so he knows to distinguish what is good and which is bad. While teaching is an attempt to fill the learner's intellectual with a number of sciences. ${ }^{12}$

HAMKA argues that the world of education should be able to bridge the Muslim youths with the true history of the country, because true history will be a source of inspiration and role model for later generations. Education must also be able to connect its learner with its main source of reference i.e. the Holy Qur'an, for deciding the Muslims of the Qur'an, thus eliminating Muslims in the region, while quoting Kyai $\mathrm{H}$. Ahmad Dahlan when it begins to move Muhammadiyah in about 1912, "Islam will not disappear from this world, but may be lost from Indonesia". ${ }^{13}$

Education in the view of HAMKA is divided into two parts. First, physical education, that is education for growth and physical perfection and the power of the soul and the mind. Secondly, spiritual education, that is education for the perfection of human nature with science and experience based on science. Both elements have a tendency to develop, and to cultivate both is through education because education is the most appropriate means in determining the optimal development of both elements. In Islamic view, the two basic elements are known by the term ' fitrah'. ${ }^{14}$

HAMKA argues that manners or morals are a supply that has been in the mind, has been planted, has been rasikh. He was the one who caused the temperament with ease so that it did not deign to the old thinking anymore. If that supply can lead to a praiseworthy manner, a noble character (noble according to reason and shara') is called good manners. However, if a blameworthy growth of wisdom and shame 'is also called bad manners. ${ }^{15}$

The authors conclude the moral education according to HAMKA is a series of efforts to develop the physical and spiritual so that raises the personality of noble character and good morality.

\section{Purpose of Morality Education Perspective of HAMKA}

\footnotetext{
12 Ibid.

${ }^{13}$ HAMKA, Dari Hati Ke Hati Tentang Agama, Sosial Budaya, Politik,, (Jakarta: Pustaka Panjimas, 2002), 106.

${ }^{14}$ Syamsul Kurniawan dan Erwin Mahrus, Jejak Pemikiran Tokoh Pendidikan Islam, 229.

${ }^{15}$ HAMKA, Akhlaqul Karimah, 4-5
} 
In the world of education, goals are a very important and fundamental issue to discuss. Because without the purpose of the implementation of the education process becomes unclear, not directed and even can get lost or misstep. According to HAMKA, every human effort in implementing various aspects of education, there must be ghayah (goal) and washilah (method). Ghayah is a statement of purpose to be realized, while washilah is the method or way to be done for that purpose. Purpose is the world of ideals, namely the ideal atmosphere to be realized. The formulation of educational objectives is a reflection of the ideality of the preparation, both instructionally and individually. Therefore, what values are aspired by the preparation of the goal will color the pattern of human personality of the educational process. ${ }^{16}$

Meanwhile, according to HAMKA himself that reveals that the goal in character education is to achieve the highest level of character or character. As for the characteristics of the height of the mind is that if man has been able to achieve i'tidal degree, that is the balance in the human soul which is the middle of the two most opposite traits namely the power of reason and lust and the virtue, that is the ultimate goal. ${ }^{17}$

In his view, i'tidal was formed on two factors, among others:

1. Thanks to God's grace over man and the perfection of his own human nature. Man was created by God equipped with reason, besides it was also endowed with lust or sexual appetite and ghadab (lust of anger). All of God's grace goes according to the livelihood of man, it is necessary to balance as determined by religion or syara'.

2. The height of manners is obtained through mujahadah, sincerity and mental practice. This means familiarizing yourself with the work that produces the mind that is demanded. For example, a person who intends to make himself a spouse, the way is to get used to charity. Should be taught the self is always accustomed good manners and generous, so finally become the character, easy to do and not feel heavy anymore. ${ }^{18}$

\footnotetext{
${ }^{16}$ Nur Hamim, Manusia Dan Pendidikan Elaborasi Pemikiran HAMKA, 86

${ }^{17}$ HAMKA, Akhlaqul Karimah, 10.

${ }^{18} \mathrm{Ibid}, 11$.
} 
The authors conclude that the goal of moral education according to HAMKA is the achievement of the highest character or morality, in the achievement of it if human beings have been able to obtain the degree of $i^{\prime}$ tidal is the balance of the human soul that includes the mind and lust or lust and virtue is the ultimate goal from character education itself.

The author agrees with the goal of moral education according to HAMKA. Because the authors do not deny that the lust, whether lust against women or the opposite sex, children, and property is a human need as Allah says: "Being made beautiful on (human) love of what is desired, namely: woman - girls, children, rich treasures of gold, silver, horse of choice, cattle and fields. That is the joy of life in the world, and in the sight of Allah is the place of good return (heaven) "(Q.S. Ali Imran [3]: 14$)^{19}$

But it should be underlined from the above verse is the best place to return is God. How does man best occupy the place of return? That is by obtaining the degree of i'tidal is the balance of the human soul that includes the mind and lust or lust, as the goal of character education perspective HAMKA through the methods that will be discussed in other sections.

\section{The material of morality education based on HAMKA}

The educational material of HAMKA consists of manifestations of God, the character of man, and the character of nature which will be explained below:

\section{Budi Pekerti Against Allah SWT}

Some material morals against God according to HAMKA that must be owned by a Muslim, namely:

a. Sincere

Human relationships to God, not between laborers and masters, but servant relations with God. The work the servant does, is not a work of God and not a return to God. But the benefits to the servant themselves.

\footnotetext{
${ }^{19}$ Kementerian Agama RI, Al-Qur'an Dan Tafsirnya: Edisi Yang Disempurnakan, Ibid, Jilid I, 692.
} 
Therefore, servant, the sincere servant follows the Lord's command because he is a servant of God. ${ }^{20}$

It is not perfect that those who hope for heaven in their charity and fear of hell, because it is no longer seeking profit for the mind. But, seeking the material for oneself. Yet, we work to uphold God's command is not because hope for a profit. We are obliged to worship Him. For we are not recompensed by our merits of ihsan. ${ }^{21}$

b. Qana'ah

Qana'ah is receiving enough. Qana'ah contains the first five cases, accepting willingly of what is. Second, ask God for a worthy addition and try. Third, accept patiently the provisions of God. Fourth, put your trust in God. Fifth, not interested in the deceit of the world. That is what is called qana'ah and that is true wealth. ${ }^{22}$

c. Taubat

Taubat is returning to the right path or to the way of God. This means that one always remembers Allah, keeps God's commandments and promises not to repeat his mistakes again which resulted in a great sin. True Taubat is not a reproach that sells tears. Do not keep on doing evil, do not accidentally approach evil. It is true that man is always misguided to error, but that is the use of religion is revealed, so that one's lust can be restrained properly do not be late to ask for repentance, because death can come suddenly, the habit of getting accustomed to doing evil, because with the habit of doing evil will like to lift themselves from the abyss of sin. Do not be accustomed to small sin, because a day a thread, long into cloth. ${ }^{23}$

d. Tawakkal (Resignation)

Tawakal is to submit a decision as a matter, endeavor and effort to the Lord of the universe. He is strong and powerful, we are weak and helpless.

\footnotetext{
${ }^{20}$ HAMKA, Lembaga Budi, 6.

${ }^{21} \mathrm{Ibid}, 7$.

${ }^{22}$ HAMKA, Tasawuf Modern, 267.

${ }^{23}$ HAMKA, Akhlaqul Karimah, 85-86.
} 
Therefore, we as weak human beings at least surrender our affairs to God but with endeavor and effort first only Allah determines. ${ }^{24}$

e. Love

The sincere intention of intention is love. Anyone who loves, sincerely obedient and holy intentions. So whatever work is done is to take the attention of pleasure than the beloved. And beautiful and perfect love is just one, God. In Him there are causes for being loved inward, no skin no longer contained. Therefore, it is He alone who deserves our pure and sincere love. So, a person who loves God with a holy love, follows his instructions. Because love stopped his ban. For love, his love is also rewarded by God. God will not waste that love. ${ }^{25}$

2. Morality toward person

The author will explain the manners of man as written in his book entitled Philosophy of Life as below:

a. Maintaining Eyes and Embroidery

The key to the greatest public safety in order to be preserved from immorality and embedded good morality is to maintain the view, both men against women and women against men. Because of that view the door into the heart and soul that cause contact between the two sides. For that to the men who believe, given the memory so that his eyes do not be wild when you see a beautiful woman or look at the body shape that lust lust and let also keep his cock. ${ }^{26}$

b. Do not Destroy Public Relations

HAMKA explains the points which are taboo which if violated will damage public relations:

1) It is forbidden for a people to denounce the other

A society is forbidden to denounce the other. It may be in the reprobate that better the virtue than the reproach. This is the

\footnotetext{
${ }^{24}$ HAMKA, Tasawuf Modern, 285.

${ }^{25}$ HAMKA, Falsafah Hidup, ‘156-157.

${ }^{26}$ Ibid, 115.
} 
only point of hatred and malicious hatred. All the good that is on the enemy is forgotten, but the error is exaggerated. So, hate blinds the eye, removes justice, as if the person who is hated or reproached does not have the slightest good. ${ }^{27}$

2) Do not slander yourself

The root of this explanation is that of others is also you. People who insult others mean insulting themselves. For with his deeds of contempt, it is obvious that he is the one who despises. So, do not insult yourselves. Though what you despise is someone else, the one who is inflicted is yourself. ${ }^{28}$

3) Do not choose bad titles

Allah SWT does not look bad or defective body. That is not what He counted in the Hereafter, but his deeds and worship. But the evil degree and the worst of the attitude to the religious view are those who formerly believed, then became ungodly. And those who do not immediately repent of their faults are the ones who are given the ungodly title by God Himself. ${ }^{29}$

4) Get rid of prejudices

This case is also important in the social life. Often, we think a friend meant to be mean to us, and then we try to find a friend like us in the case. And finally cause rifts and disputes. ${ }^{30}$

5) Do not duplicate your face

Prejudice that has been described above will become greater if accompanied by two-faced newsletters. Which is good here mouth. Who are looking for bad news to deepen the chasms of division and hostility. Such acts are so lowly and lowly. Because it can damage the relationship of human beings and is

\footnotetext{
${ }^{27}$ Ibid, 123

${ }^{28}$ Ibid., 125.

${ }^{29}$ Ibid.

${ }^{30}$ Ibid., 126.
} 
prohibited by religion and morals because the person has eliminated the sense of humanity. ${ }^{31}$

6) Do not like to talk about the disgrace of your brother behind

This is the greatest society's disease. Deliberately digging the opponent's cheek, as if the one who denounced it was an angel. The act is cursed or talking gossip. Gossip is equated with the carnivorous carcass of his friend. Islam forbids the act, even though the person in question is guilty. For no man is loose than false. Though he was wrong, he may have made a mistake for his mistakes and may have been repentant. ${ }^{32}$

c. Respect your Parents

Respect and love your parents belong to the most important pillars of society and courtesy that is the mother of all modesty. No matter how advanced the steps of people in the social life, however famous his name and rich in his style, he cannot be named a polite if he has not shown his devotion to both his parents.

So, the love of mother and father to a child never expects a reward at all and there is no sacrifice beyond the sacrifice of a mother. Sometimes the mother forgot herself, forgot to decorate her body, forget to eat and drink, provided the child is healthy. When a child has a fever is not the more suffered it is the child but his own mother who felt very miserable. ${ }^{33}$

Later after the adult the child will be separated from the responsibilities of parents, who men up their own households, have children, women who obey their husbands, while those who live in his mother remain a memento. Love father is no less than the mother's love. For what a man works for a living, go early in the morning and come home that night for the sake of his family including his son for the happiness of his son also the parents willing to sacrifice anything.

${ }^{31} \mathrm{Ibid} ., 128$.

${ }^{32}$ Ibid., 129.

${ }^{33}$ Ibid., 132-133. 
So, let us as children always respect them, obey them and do not both wasted because the love of parents will not be comparable with the love of the child against him because the mother risked his life for the child's birth. ${ }^{34}$

3. Morality towards Nature

Nature is decorated for us with the sun and the moon, the stars and the horizons, they are reserved for us. Plants, crops, forests, and terrestrial and terrestrial groves, all attributed to our lives. ${ }^{35}$ Allah says: "It has been seen that the destruction on land and in the sea is caused by the deeds of the hands of men, that God may feel to them a part of their (effect) their actions, that they may return (to the right path). Say: "Take the journey of the earth, and see what the end of is the former, most of them partners (Allah)" (Surat al-Rum 30: 41-42) ${ }^{36}$

HAMKA interprets the above verse as follows: "Sometimes we are wondering about this verse. Because he can be interpreted in accordance with the development of today. For example, about the damage occurring on land because of man-made traces is what they call pollution. Which means air pollution, due to smoke from burners, kerosene, gasoline, diesel and so on. The dirty air is sucked at all times, so the human lungs are full of dirt. These are all half of the former human. And at the end of the verse is called to make people think, hopefully they come back. The meaning of the return is very deep. It means to re-examine yourself and to correct the intentions, to improve the relationship with God again. Do not just remember your own profits, then harm others. "37

The authors conclude that keeping the environment is important because maintaining the environment is the same as worshiping Allah and strengthening humanity because the environment is created by God and used by other human beings wisely.

\footnotetext{
${ }^{34}$ Ibid, 134.

${ }^{35}$ HAMKA, Lembaga Budi, 8.

${ }^{36}$ Kementerian Agama RI, Al-Qur'an Dan Tafsirnya: Edisi Yang Disempurnakan, Ibid, Jilid VII, 513-514.

${ }^{37}$ HAMKA, Tafsir Al-Azhar, Ibid, juz 21, 95-96.
} 


\section{A Method of Morality Education Based On HAMKA}

According to the author, in inculcating the most outstanding character of HAMKA is using the method of virtue, exemplary methods, methods of habituation, and methods of live in. Below we will explain the method of virtue and exemplary method of perspective of HAMKA.

1. Method of Priority

The concept of virtue originated from a central question put forward by Aristotle in his lecture notes which his child then compiled into a book called Ethika Nechomachea. The questions are, "what is the good of man?" And the answer is "the good of man is the activity of the soul in accord with virtue". ${ }^{38}$

The main according to Ahmad Amin, is the will of a person by getting used to something good. Thus, the main person is a person who has good morality that accustom to choose actions in accordance with what is ordered by religion, so the virtue is the nature of the soul. ${ }^{39}$ According to HAMKA, the main one is the person who holds a simple stance, thinking about the interests of his family with the interests of the people and the nation and the public generally.

Growing in his heart that as a living person he is obliged to do good to all the animate, human or animal and himself though. The virtue takes place after the inner struggle, in life there is always a struggle between the lust and the sane mind. Lust invites to do the harmful and the intellect invites to do useful things. ${ }^{40}$

The struggle meant by HAMKA is to develop iffah and syaja'ah. Iffah is the ability to hold back. The point is for self-restraint not to go through a satisfaction that ultimately brings self-pity to sinfulness. Syaja'ah means for the generation of courage to take a pain that needs to make life useful. ${ }^{41}$

\footnotetext{
${ }^{38}$ James Rachels, Filsafat Moral, (Yogyakarta: Kanisius, 2004), 306.

${ }^{39}$ Mustafa, Akhlak Tasawuf, (Bandung: Pustaka Setia, 2010), cet. Ke-V, 142.

${ }^{40}$ HAMKA, Falsafah Hidup, 84.

${ }^{41}$ Ibid., 86.
} 
HAMKA gives an example, a sick person who will recover if any part of his body is operated on. If the sick fear of surgery would be the greater the danger. Then he must dare to face the operation for his own benefit. Similarly, clever refrain when encountering unfavorable satisfaction. For example, the pleasure of fornication. If there is no iffah temperament embedded in him he will certainly do adultery. Because it is delicious on the body but suffering is painful for the soul and damages the mind and the descendants. ${ }^{42}$

2. Method of Habituation

Based on the life history of HAMKA that was educated hard by his father, then HAMKA would not have to be accustomed to read religious books. But over time, HAMKA also used to read nonreligious books such as philosophy, literature, politics, and so on. In addition to reading, HAMKA is also familiar with writing. This is because the encouragement of his teacher in Sarekat Islam, H.O.S. Tjokroaminoto that HAMKA can voice his thoughts through writing. ${ }^{43}$

According to the authors, HAMKA has dozens of books because of its habit of reading and writing. The books related to manners are Akhlaqul Karimah, Lembaga Budi, Institution of Life, Philosophy of Life, and Modern Sufism. In addition, HAMKA says that the height of manners can be acquired by familiarizing oneself with the work that results in the manifestation of the required character. For example, if all this time he was arrogant, then the way is to familiarize themselves as people who are virtuous tawadhu'. Guided and forced themselves, so that eventually tawadhu 'it becomes a manner that arise. ${ }^{44}$

3. Exemplary Method

According to the authors, the positive values of attitudes and behavior of HAMKA are exemplified by his teachers, especially his

\footnotetext{
${ }^{42}$ Ibid.

${ }^{43}$ Ibid., 230.

${ }^{44}$ HAMKA, Akhlaqul Karimah, 11.
} 
father. His father who continues to support HAMKA so he becomes a useful child for religion and society. Although in his childhood often oppose his father, but over time, HAMKA realize that his father is a good role model. ${ }^{45}$ And in 1950, HAMKA published a biography book about his father whom he named "My father".

In addition, HAMKA also provides exemplary examples. For example, when President Sukarno died, HAMKA continued to exercise his will to transmit his body. HAMKA was willing and HAMKA did sincerely without revenge although former President Sukarno ever imprisoned HAMKA for alleged dissidents and rebels. ${ }^{46}$

4. Live in Method

As explained in chapter II, the live-in method gives children the experience to live with others directly in totally different situations from everyday life. From here HAMKA prefers to seek experiences in its own way. Learning in his own way proved to be more effective than just sitting and locking himself in the classroom while listening a lecture teacher. ${ }^{47}$

According to the author, HAMKA get a lot of knowledge, especially manners from various places. One of them, when HAMKA sick pox in Bengkulu when he was about to escape to Java. He was treated until healed by a husband and wife there while others are reluctant to help him. From the incident, HAMKA decided to return home and apologize for the attitude and behavior that hurt his father. $^{48}$

\section{Conclusions}

\footnotetext{
${ }^{45}$ Haidar Musyafa, HAMKA: Sebuah Novel Biografi, 54.

${ }^{46}$ Haidar Musyafa, Jalan Cinta Buya: Buku Kedua Dari Dwilogi HAMKA, 425-434.

${ }^{47}$ Ibid., 35

${ }^{48}$ Ibid., 136-138.
} 
The results of this study conclude that the concept of moral character education perspective based on Al-Qur'an and Sunnah Rasulullah SAW and Reason. The goal of human rights perspective education is to reach the $i^{\prime}$ tidal (soul balance) achieved by developing four factors, namely syaja'ah, 'iffah, wisdom, and' is. A prominent method of education is the method of virtue, exemplary method, live in method, and method of habituation. The most appealing evaluation for character education of human rights perspective is muhasabah (self-evaluation).

\section{References}

Arifin, Zainal. Evaluasi Pembelajaran: Prinsip, Teknik, Prosedur. Bandung: Remaja Rosdakarya, 2013

_Bungin, Burhan. (ed). Metodologi Penelitian Kualitatif. Jakarta: Raja Grafindo Persada, 2007

Daradjat, Zakiah. dkk.. Ilmu Jiwa Agama. Jakarta: Bulan Bintang, 1996 . Ilmu Pendidikan Islam. Jakarta : Bumi Aksara, 1992 Daryanto. Evaluasi Pendidikan. Jakarta: Rineka Cipta, 1999

HAMKA. Akhlaqul Karimah. Jakarta: Pustaka Panjimas, 1994 Dari Hati Ke Hati Tentang Agama, Sosial Budaya, Politik. Jakarta: Pustaka Panjimas, 2002 . Falsafah Hidup. Jakarta: Republika, 2017 Lembaga Budi. Jakarta: Republika, 2016 . Pandangan Hdup Muslim. Depok: Gema Insani, 2016 . Pelajaran Agama Islam. Jakarta: Bulan Bintang, 1996 . Tafsir al-Azhar Juz I-XXX. Jakarta: Panjimas, 1992 . Tasawuf Modern. Jakarta: Republika, 2017

Mas'ud, Ali. Akhlak Tasawuf. Sidoarjo: Dwiputra Pustaka Jaya, 2012 Masy'ari, Anwar. Akhlak Al-Qur'an. Surabaya: Bina Ilmu, 1990

Moleong, Lexy J.. Metodologi Penelitian Kualitatif. Bandung: Remaja Rosdakarya, 2001 
Musyafa, Haidar. HAMKA: Sebuah Novel Biografi. Tangerang Selatan: Imania, 2017 - Jalan Cinta Buya: Buku Kedua Dari Dwilogi HAMKA. Tangerang Selatan, Imania 2017

Nasution, Harun. Akal Dan Wahyu dalam Islam. Jakarta: UI Press, 1986 Nata, Abuddin. Akhlak Tasawuf. Jakarta: Raja Grafindo Persada, 1997 Filsafat Pendidikan Islam, Jakarta: Logos Wacana Ilmu, 1997

Rahardjo. dkk.. Pemikiran Pendidikan Islam: Kajian Tokoh Klasik Dan Kontemporer. Yogyakarta: Pustaka Pelajar, 1999

Ramayulis. Ilmu Pendidikan Islam. Jakarta : Kalam Mulia, 1998 Metodologi Pendidikan Agama Islam. Jakarta: Kalam Mulia, 2005 Saebani, Beni Ahmad. Ilmu Akhlak. Bandung: Pustaka Setia, 2010

Shihab, M. Quraish. Membumikan al-Qur'an. Bandung: Pustaka Mizan, 1993 . Tafsir Al-Mishbah: Pesan, Kesan, Dan Keserasian al-Qur'an, Jilid I$X V$. Jakarta: Lentera Hati, 2007

Wawasan Al-Qur'an: Tafsir Maudhu'i Atas Berbagai Persoalan Umat. Bandung: Mizan Media Utama, 2000

Tafsir, Ahmad. Ilmu Pendidikan Dalam Perspektif Islam. Bandung: Remaja Rosdakarya, 1992

Tamara, Nasir. dkk.. HAMKA Di Mata Umat, Jakarta: Sinar Harapan, 1984

Zuriah, Nurul. Pendidikan Moral Dan Budi Pekerti Dalam Perspektif Perubahan. Jakarta: Bumi Aksara, 2007 